\begin{tabular}{|l|l|l||}
\hline \multicolumn{2}{|c|}{ PublisherInfo } \\
\hline \hline PublisherName & $:$ & BioMed Central \\
\hline \hline PublisherLocation & $:$ & London \\
\hline \hline PublisherImprintName & $:$ & BioMed Central \\
\hline \hline
\end{tabular}

\title{
Role of C5 in CIA
}

\begin{tabular}{|l|l|l||}
\hline \multicolumn{2}{|c||}{ ArticleInfo } \\
\hline \hline ArticleID & $:$ & 9 \\
\hline \hline ArticleDOI & $:$ & $10.1186 /$ ar-2000-66807 \\
\hline \hline ArticleCitationID & $:$ & 66807 \\
\hline \hline ArticleSequenceNumber & $:$ & 5 \\
\hline \hline ArticleCategory & $:$ & Paper Report \\
\hline ArticleFirstPage & $:$ & 1 \\
\hline \hline ArticleLastPage & $:$ & 3 \\
\hline \hline & $:$ & RegistrationDate : 2000-5-8 \\
ArticleHistory & $:$ & OnlineDate \\
\hline \hline ArticleCopyright & $:$ & Current Science Ltd2000-5-8 \\
\hline \hline ArticleGrants & $:$ & \\
\hline \hline ArticleContext & $:$ & 130752211 \\
\hline \hline
\end{tabular}

This PDF file was created after publication. 
Aff1 Imperial College School of Medicine, London

\section{Keywords}

Arthritis, C5,complement, gene-disruption, mouse

\section{Context}

CIA displays immunologic and histopathogenic similarities to RA and is therefore often used as a model for human RA. Both cellular and humoral immune mechanisms contribute to disease pathogenesis. Studies to evaluate the role of complement in CIA, in particular the pro-inflammatory byproducts generated by activation of the $\mathrm{C} 5$ component, have led to conflicting conclusions. The generation of C5-deficient animals on a background strongly associated with CIA susceptibility will contribute to understanding the role of complement in autoimmune arthritis. Generation of inbred DBA/ $1 \mathrm{LacJ}$ mice congenic for a mutant C5 allele. Assessment of the ability of such C5-deficient mice to mount cellular and humoral responses to native type II collagen and examination of the susceptibility of these mice to CIA.

\section{Significant findings}

Functional complement deficiency of the C5D-DBA/1 mice was confirmed by measuring the hemolytic activity. When immunized and then boosted with heterologous BCII, clinically severe arthritis was observed in $90 \%$ wild-type DBA/1 LacJ mice and in $100 \%$ of C5S-DBA/1. In marked contrast only 3 of $20(15 \%)$ immunized C5D-DBA/1 mice had clinically significant arthritis. The dependency in was also noted in mice boosted with autologous MCII as demonstrated by a complete absence of CIA in 10 immunized C5D-DBA/ 1 mice, in contrast to a greater than $90 \%$ incidence in similarly challenged DBA/ 1LacJ animals. C5D-DBA/1 mice were shown to mount $\mathrm{T}$ cell proliferative responses to both $\mathrm{BCII}$ and MCII similar to those seen in the wild-type DBA/1 LacJ mice. TNF-Î' ${ }^{2}$ production in $\mathrm{CD}^{+} \mathrm{T}$ cells from C5D-DBA/1 mice was also equivalent. Assessment of humoral responses revealed comparable levels of heterologous and autologous collagen-specific IgG, with similar isotype distribution, elicited in primed arthritis-free C5D-DBA/ 1 and arthritic C5S-DBA/ 1 mice. The arthritis in the three C5D-DBA/ 1 mice that developed disease was histologically similar to that of C5S-DBA/1 littermates. Of particular note, immunohistochemical analysis revealed equivalent intra-articular deposition of $\operatorname{IgG}$ and $\mathrm{C} 3$ on the cartilaginous surfaces of both primed C5D-DBA/1 and primed C5S-DBA/1 mice. Arthus reactions after intradermal injection of CII were similar in both C5D and C5S animals. Thus in actively immunized 
C5D-DBA/1 mice, pathologic inflammatory responses were elicited after antigen binding and deposition of collagen-specific antibodies in the skin but not in the joint.

\section{Comments}

This interesting paper demonstrates the critical role of complement in the pathogenesis of arthritis in DBA/1LacJ mice. The striking resistance to collagen-induced arthritis (CIA) noted in C5-deficient animals, despite immunoglobulin (Ig) and C3 deposition, provides clear evidence that complement plays a major role in immune-complex triggered inflammation. T-cell function was shown to be unchanged but was limited to tumor necrosis factor (TNF)- $\hat{I}^{2}$ induction. The analysis of other cytokines pertaining to changes in Th1/Th2 phenotype would have enhanced the investigation. The study supports the rationale for inhibition of complement to combat rheumatoid arthritis (RA) and, as the authors suggest, perhaps further clinical benefit could be achieved from concurrent complement and cytokine blockade.

\section{Methods}

C5D B10.D2/oSn mice were backcrossed with DBA/1LacJ mice for six generations and then intercrossed to produce homozygous C5-deficient DBA/1 mice (C5D-DBA/1) and C5-sufficient DBA/1 (C5S-DBA/1) lines. The C5 genotype was determined by PCR. Bovine type II collagen (BCII) or mouse type II collagen (MCII) was used to induce CIA 21 days after the initial immunization. Arthritis was measured by scoring each forepaw and hindpaw. At 6 weeks after the initial immunization, histologic evaluation was carried out (H \& E) and intra-articular IgG and complement deposition determined by immunofluorescence staining. $\mathrm{T}$ cell stimulation assays (assessed by [3H]thymidine uptake) were carried out on lymph node cells taken from animals 7-10 days after reimmunization with BCII. Analysis of BCII-induced production of TNF- ${ }^{2}$ was by intracellular immunofluorescence using phycoerythrin (PE)-labled anti-TNF-ÎI ${ }^{2}$ monoclonal antibodies and fluorescein iscthiocyanate (FITC)-conjugated rat anti-mouse CD4 and anti-mouse CD8. Anti-BCII antibodies in the serum were quantified by ELISA 35 days after initial immunization. Direct Arthus reactions were performed by intradermal injection of BCII 45 days after initial immunization.

\section{References}

1. Wang Y, Kristan J, Hao L, Lenkoski CS, Shen Y, Matis LA: A role for complement in antibodymediated inflammation: C5-deficient DBA/1 mice are resistant to collagen-induced arthritis. J Immunol. 2000, 164: 4340-4347.

This PDF file was created after publication. 